\title{
Fructosamine as a Tool on the Evaluation of Insulin Resistant Obese Dogs
}

Veiga, A.P.M., Adjoint Professor, Universidade Federal de Santa Catarina (UFSC) - Campus Curitibanos. Rod. Ulysses Gaboardi, Km 03. Fazenda Pessegueirinho. Caixa Postal 101, Curitibanos, Santa Catarina, Brasil. E-mail: angela.veiga@ufsc.br

Stedile, S.T.O, Adjoint Professor, Universidade Federal do Paraná, Setor de Ciências Agrárias, Rua dos Funcionários, 1540, Departamento de Medicina Veterinária, Juveve, Curitiba, PR, Brasil E-mail: tostesimone@gmail.com

Santos, A.P., Graduate TA - CPB Clinical Pathology, Purdue University College of Veterinary Medicine, 625 Harrison Street, West Lafayette, IN 47907, Email: santos1 @ purdue.edu

Santos, W.I.M., D.V.M. Undergraduate Student, Universidade Federal de Santa Catarina (UFSC) Campus Curitibanos. Rod. Ulysses Gaboardi, Km 03. Fazenda Pessegueirinho. Caixa Postal 101, Curitibanos, Santa Catarina, Brasil. E-mail: wislley_malaquias@ hotmail.com

González, F.H.D, Adjoint Professor, Universidade Federal do Rio Grande do Sul, Faculdade de Veterinária, Av. Bento Gonçalves, 9090 - Bairro Agronomia - Porto Alegre - Rio Grande do Sul Email: felixgonzalez.ufgrs@gmail.com

\begin{abstract}
Fructosamine is the glycated form of blood proteins. The determination of its levels is useful to evaluate glycaemia. To verify the effect of insulin resistance on the levels of fructosamine in obese dogs, three groups of healthy animals were used: control $(n=13)$, insulin sensitive obese $(n=6)$ and insulin resistant obese $(n=9)$. After a 12-hour fasting the animals were submitted to blood collection for glucose, triglycerides, fructosamine, and insulin serum levels measurements. Thirty minutes after venous administration of glucose $(0.5 \mathrm{~g} / \mathrm{kg})$, glycemia was determined. Obese dogs were grouped into insulin sensitive and insulin resistant through fasting insulin/glucose ratio calculation. ANOVA analysis was used considering a 95\% level of significance and for comparison between groups Student's t test was used. Pearson's correlation coefficient was determined between the measured parameters. Insulin resistant obese group had higher values of basal insulin $(p<0.001)$, fructosamine $(p<0.05)$ and insulin/glucose ratio $(p<0.0001)$, while insulin sensitive obese dogs showed higher postprandial glycaemia $(p<0.01)$. A positive correlation between fructosamine and postprandial glycaemia; and fructosamine and insulin/glucose ratio was detected $(r=0.4 ; p<0.05)$. Both obese groups showed lower levels of basal glycaemia and higher serum concentrations of triglycerides than control $(p<0.05)$. Fructosamine showed to be a useful tool for insulin resistance evaluation.
\end{abstract}

Keywords: obesity, metabolic syndrome, glycaemia, dogs, fructosamine

\section{INTRODUCTION}

The prevalence of obesity is becoming higher in companion animals, thus increasing the susceptibility to a number of diseases, being the most commonly found $[1,2]$ The evaluation of obesity and its treatment can avoid the development of more serious and incurable diseases. For such, the study of easily performing clinical techniques to access insulin resistance is crucial. Fructosamine consists of a non-enzymatic and irreversible chemical reaction between glucose and amino acid residues originated from systemic proteins, being an useful and efficient tool to evaluate glycaemia of one to three previous weeks $[2,3,4]$. Though the increase in fructosamine serum level is well documented in diabetic dogs and cats $[2,3,5,6,7]$ and that such an increase is related with hyperglycemia $[2,4,8]$, no consistent study in dogs was conducted in order to evaluate the effect of insulin resistance on serum levels of fructosamine, essentially considering euglycemic animals [9]. Nevertheless, studies in humans showed low serum levels of fructosamine in obese subjects compared with control, while others [10] demonstrated hyperlipidemia as one of the causes for this decrease $[4,11]$. That exposed, the aim of this study was to verify the effect of insulin resistance on serum levels of fructosamine in 
non-diabetic, naturally obese dogs, as an hypothesis that fructosamine is under influence of insulin resistance and may be used in future as an important tool in this sort of metabolic alteration in dogs.

\section{Material AND Methods}

Body weight and 9-points body condition score (BCS) based on reports of Laflamme [12] determination of 28 dogs were performed, with the following body condition measurements: $1=$ emaciated, $3=$ lean, $5=$ ideal, $7=$ overweight, $9=$ obese. The measurement was performed by three different subjects, getting to a mean value. According to the measured aspects and insulin/glucose ratio $(\mathrm{I} / \mathrm{G})$ the dogs were subclassified in 3 groups: control $(\mathrm{n}=13$, BCS $3-5, \mathrm{I} / \mathrm{G}<0.235)$; insulin sensitive obese $\operatorname{dogs}(n=6$, BCS $7-9, \mathrm{I} / \mathrm{G}<0.235)$; insulin-resistant obese dogs $(n=9$, BCS 7 - 9, insulin/glucose ratio $>0.235$ ). Previously, the dogs were attested as healthy through clinical and laboratorial examinations, except for obesity in the groups composed by obese dogs. The animals were kept in fasting conditions for approximately 12 hours, when they were submitted to blood collection for serum measurements of fructosamine (nitrobluetetrazolium method, Labtest Diagnostic, Lagoa Santa, MG, Brazil), insulin (radioimmunoassay method, Linco Reserch, Billerica, MA, USA), glucose (glucose-oxidase method, Accu-Check Active, Roche Diagnostics, São Paulo, SP, Brazil), and triglycerides (glycerol phosphate oxidase method, Labtest Diagnostic, Lagoa Santa, MG, Brazil). I/G ratio was calculated as a measurement of insulin sensitivity. Those animals which I/G > 0,235 were considered insulin resistant [13]. Glucose $50 \%$ was injected at $0.5 \mathrm{~g} / \mathrm{kg}$ through cephalic vein. A new blood collection was performed through contralateral cephalic vein to avoid the mixture of the previously injected glucose with blood, after 30 minutes of glucose administration, for glucose determination. This study was approved by Universidade Federal do Rio Grande do Sul Ethic Committee and all recommended principles related to the experimental use of animals were considered (Brazilian College of Animal Experimentation).

Statistical analysis was performed through JMP 5.1 (SAS Institute, Cary, NC, USA), where a parametric test was used. ANOVA was applied and means were compared through Student's t test. Pearson's correlation coefficient was used to correlate the variables. A level of $\mathrm{P}<0.05$ was considered significant.

\section{RESUlts}

Mean, standard error of measurements, maximum and minimal values from the variables studied between controls, insulin sensitive, and insulin resistant obese groups are described in Table 1. Obese groups showed lower fasting glucose levels compared to control group $(\mathrm{p}<0.05)$.

Table 1. Mean, standard error of mean (SEM), maximum and minimum values of the studied variables in control (lean), insulin-sensitive, and insulin-resistant obese dogs

\begin{tabular}{|l|l|l|l|}
\hline Parameter & Control & $\begin{array}{l}\text { Insulin sensitive obese } \\
\text { dogs }\end{array}$ & $\begin{array}{l}\text { Insulin resistant obese } \\
\text { dogs }\end{array}$ \\
\hline $\begin{array}{l}\text { Basal glucose } \\
(\mathrm{mg} / \mathrm{dL})\end{array}$ & $\begin{array}{l}94.0 \pm 3.86^{\mathrm{a}} \\
(86.1-109.2)\end{array}$ & $\begin{array}{l}81.7 \pm 4.01^{\mathrm{b}} \\
(71.3-92)\end{array}$ & $\begin{array}{l}82.9 \pm 3.62^{\mathrm{b}} \\
(74.5-91.2)\end{array}$ \\
\hline $\begin{array}{l}\text { Basal insulin } \\
(\mu \mathrm{U} / \mathrm{mL})\end{array}$ & $\begin{array}{l}11.28 \pm 1.33^{\mathrm{b}} \\
(8.4-14.2)\end{array}$ & $\begin{array}{l}11.39 \pm 2.05^{\mathrm{b}} \\
(6.1-16.7)\end{array}$ & $\begin{array}{l}32.8 \pm 6.62^{\mathrm{a}} \\
(17.5-48.1)\end{array}$ \\
\hline Insulin / glucose ratio & $\begin{array}{l}0.118 \pm 0.01^{\mathrm{b}} \\
(0.09-0.15)\end{array}$ & $\begin{array}{l}0.145 \pm 0.03^{\mathrm{b}} \\
(0.07-0.22)\end{array}$ & $\begin{array}{l}0.385 \pm 0.06^{\mathrm{a}} \\
(0.24-0.53)\end{array}$ \\
\hline $\begin{array}{l}\text { Fructosamine } \\
(\mu \mathrm{mol} / \mathrm{L})\end{array}$ & $\begin{array}{l}197 \pm 13.8^{\mathrm{b}} \\
(166-227)\end{array}$ & $\begin{array}{l}259 \pm 37.4^{\mathrm{a}, \mathrm{b}} \\
(163-355)\end{array}$ & $259.6 \pm 21.6^{\mathrm{a}}$ \\
\hline Postprandial glucose (mg/dL) & $94.8 \pm 5.44^{\mathrm{b}}$ & $139.2 \pm 21.55^{\mathrm{a}}$ & $113.1 \pm 10.77^{\mathrm{a}, \mathrm{b}}$ \\
$(82.9-106.6)$ & $(83.8-194.5)$ & $(88.3-137.9)$ \\
\hline $\begin{array}{l}\text { Area under the glycemic curve } \\
\text { 0- } \text { 30 minutes (mg/dL) }\end{array}$ & $2839.6 \pm 99.4^{\mathrm{a}}$ & $3312 \pm 326.5^{\mathrm{a}}$ & $2940 \pm 185.6^{\mathrm{a}}$ \\
\hline $\begin{array}{l}\text { Triglycerides } \\
(\mathrm{mg} / \mathrm{dL})\end{array}$ & $(2623-3056)$ & $(2473-4152)$ & $8912-3368)$ \\
\hline
\end{tabular}

*Different letters on the same line indicate statistical difference $(\mathrm{p}<0.05 ; t$ Test).

The dogs from insulin resistant obese group presented higher fasting serum insulin levels $(p=0.0003$ ) when compared to control and insulin sensitive obese groups $(\mathrm{p}=0.0023)$. No difference was detected between control and insulin sensitive obese groups. 
Insulin-resistant obese animals showed higher serum fructosamine values when compared to controls. No difference was observed when insulin-resistant and insulin-sensitive, or control and insulinsensitive groups were compared. The correlation between such a metabolite and postprandial glycaemia, as well as I/G ratio was positive (Figures 1 and 2).

Insulin-resistant obese showed higher I/G ratio values than controls $(\mathrm{p}<0.0001)$ and than insulinsensitive obese animals $(\mathrm{p}=0.00046)$. No changes were detected at the comparison between controls and insulin-sensitive obese dogs.

Thirty minutes after venous glucose administration, insulin-sensitive obese group showed higher glycaemia $(\mathrm{p}=0.0025)$ when compared to control group. No difference was observed when both groups of obese dogs, as well as controls and insulin-resistant obese dogs were compared.

Both groups of obese dogs showed higher serum levels of triglycerides than controls $(p=0.0297)$, nevertheless no difference was noticed between insulin-resistant and insulin-sensitive obese dogs.

\section{DisCUSSION}

The data presented in Table 1 and Figures 1 and 2 demonstrate the importance of serum determination of fructosamine on the evaluation of insulin resistance in dogs. Interestingly, obese dogs showed lower basal glucose levels, even with all dogs from the study being euglycaemic. Previous studies showed no difference among obese and control dogs in glycaemia and all dogs of such a study were mildly hypoglycaemic, what was related to a long period of fasting or to an alimentary imbalance [9]. Other researchers observed that insulin resistant obese dogs keep their glucose concentrations inside reference range [14]. The lower measurements of glucose observed in the present experiment in obese dogs were expected due to the higher stimulus of insulin in obese than in control animals, since serum basal insulin levels were higher in insulin-resistant dogs than in other groups, which agrees with data reported in dogs [15] and other species [10,16, 17]. It is difficult to access insulin sensitivity in clientowned animals, as the ones that composed the present study. High levels of fasting insulin and I/G ratio have been used as indirect measures of this metabolic unbalance $[1,16,18,19]$. Expectedly higher values of $I / G$ ratio were found in insulin-resistant dogs, since this index was used to group the animals. The value of 0.235 was considered as determinant of insulin resistance of the present study, based in early publications [13].

Notwithstanding their lower basal glucose levels, insulin sensitive obese group showed higher postprandial glycaemia of 30 minutes when compared to controls, with no difference being reached between insulin-resistant and control animals (Table 1). This result could be explained because insulin-sensitive animals have lower levels of insulin than the other groups. Additionally, when the area under the glycemic curve between basal and 30 minutes-period was compared between groups, no difference was detected (Table 1). Moreover, a positive correlation between postprandial glycaemia and serum fructosamine was observed at the present study (Figure 2), in discordance with what was reported in healthy dogs, where no difference was shown in serum fructosamine in different moments of the glycemic curve [20].

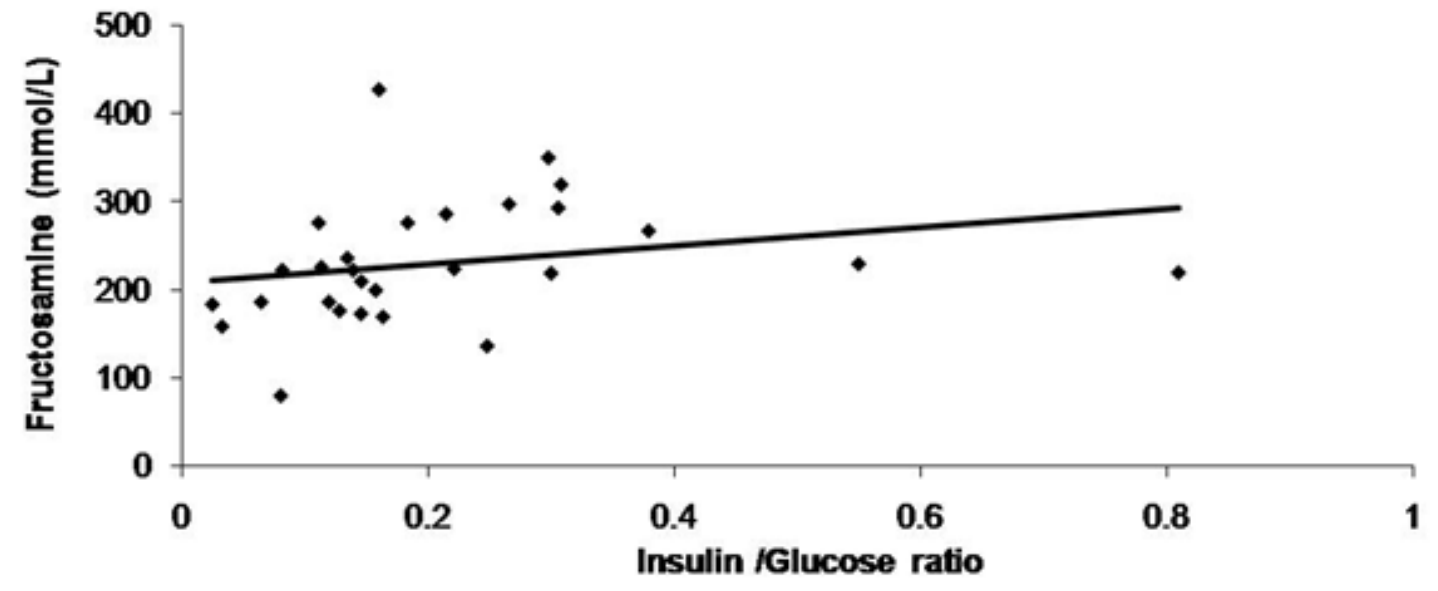

Figure 1. Correlation between levels of fructosamine and Insulin/Glucose ratio in control and obese dogs $(r=0.4 ; p=0.039)$ 


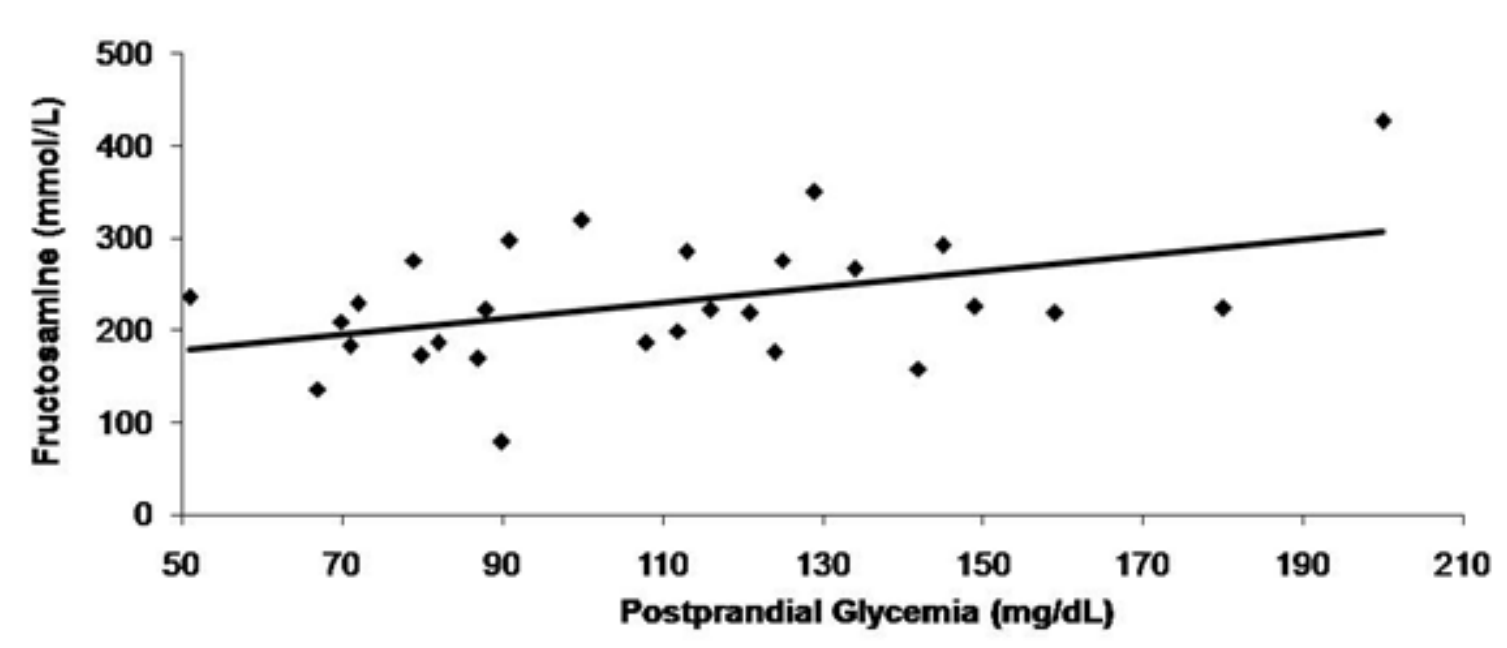

Figure 2. Correlation between levels of fructosamine and postprandial glucose in control and obese dogs $(r=0.4385 ; p=0.0196)$

Despite all groups of the present study show values of fructosamine inside reference range, as indicated by Beltrame and Reis [2,3], those values were higher in insulin-resistant obese dogs than in controls, as described in human subjects [17] and dogs [2] and a positive correlation between serum levels of fructosamine and I/G ratio was detected (Figure 1). Clinically, this suggests the existence of episodes of higher glycaemia in insulin-resistant than in control dogs at the present study [4]. Reusch \& Haberer and Bennet $[4,11]$ reported that fructosamine can be inhibited by hyperlipidemia and Broussole et al. [10] evidenced that serum levels of fructosamine are decreased in obese subjects compared with controls. On the present study, although obese dogs showed higher levels of triglycerides, what could be collaborated to the development of hyperlipidemia, this effect was not observed, agreeing with other studies [2]. Thus, one can state that fructosamine is a good parameter for the evaluation of insulin resistance, since other methods (insulin or glucose tolerance test, hyperinsulinemic clamp) are more time-consuming, expensive, and are also more stressful for the animal. Previous studies evaluated the behaviour of fructosamine in relation to glycaemia and obesity in dogs $[2,3,8,20,21,22]$, but none of them studied the effect of insulin resistance on it. Moreover, in one study where the effect of obesity was evaluated [22] a comparison was made between overweight and obesity, without control dogs. In another study where the levels of fructosamine and glucose tolerance test were analysed [21] lacked to evaluate obese animals. Thus, on the authors' knowledge, there are no data in the literature regarding insulin resistance and obesity effects on fructosamine serum levels in dogs, making the findings presented here innovative.

\section{Conclusion}

In conclusion, this study showed that fructosamine is higher in insulin resistant obese dogs, compared to lean dogs, suggesting that this metabolite can clinically be measured to evaluate dogs with such abnormality.

\section{ACKNOWLEDGEMENTS}

The authors thank Waltham Foundation and National Bureau of Scientific and Technologic Development $(\mathrm{CNPq})$ for the financial support.

\section{REFERENCES}

[1] German A.J., Hervera M., Hunter L., Holden S.L., Morris P.J., Biourge V., \& Trayhurn P. 2009. Improvement in insulin resistance and reduction in plasma inflammatory adipokines after weight loss in obese dogs. Dom. Anim. Endocrinol. 27:214-226.

[2] Reis A.B.G. 2013. Avaliação da lipemia, glicemia e leptinemia em cadelas obesas e com neoplasia mamária. Dissertação de Mestrado em Saúde Animal. Universidade de Brasília. 89 p.

[3] Beltrame O.C. 2011. Padronização da metodologia para determinacyão das concentricões sanguíneas de hemoglobin glicada e frutosamina em cães sadios, diabéticos e sob insulinoterapia. 
Dissertação de Mestrado em Ciências Veterinárias, Universidade Federal do Paraná. 63p.

[4] Bennet N. 2002. Monitoring techniques for diabetes mellitus in dogs and cats. Clin. Tech. Small Anim. Pract. 17:65-69.

[5] Reusch C.E., Liehs M.R., Hoyer M. \& Vochezer R. 1993.Fructosamine: A new parameter for diagnosis and metabolic control in diabetic dogs and cats. J. Vet. Intern. Med. 7:177-182.

[6] Jensen A.L. 1995. Glycated blood protein in canine diabetes mellitus. Vet. Rec. 137:401-405.

[7] Plier M.L., Grindem C.B., Macwilliams P.S. \& Stevens J.B. 1998. Serum fructosamine concentration in nondiabetic and diabetic cats. Vet. Clin. Path. 27:34-39.

[8] Loste A. \& Marca M.C. 2001. Fructosamine and glycated haemoglobin in the assessment of glycaemic control in dogs.

[9] Faria P.F., Araújo D.F. \& Soto-Blanco B. 2005. Glicemia em cães obesos e senis. Acta Scient. Vet. 33:47-50. Vet. Res. 32:55-62.

[10] Broussole C., Tricot F., Garcia I., Orgiazzi J., Revol A. 1991. Evaluation of the fructosamine test in obesity: consequences for the assessment of past glycemic control in diabetes. Clin. Biochem. 24:203-209.

[11] Reusch C.E. \& Haberer B. 2001. Evaluation of fructosamine in dogs and cats with hypo- or hyperproteinemia, azotaemia, hyperlipidaemia and hyperbilirubinaemia. Vet. Rec. 148:370-376.

[12] Laflamme D.P. 1997. Development and validation of a body condition score system for dogs. Can. Pract. 22:10-15.

[13] Kogika M.M., Brandão L.P., Jerico M.M., Hagiwara M.K., Simões D.M.N. \& Mendonça B. 2001. Determinação das concentrações séricas de glicose e insulina de cães em choque endotóxico. Cienc. Rural. 31:813-817.

[14] Verkest K.R., Fleeman L.M., Morton J.M., Ishioka K. \& Rand J.S. 2011. Compensation for obesity-induced insulin resistance in dogs: assessment of the effects of leptin, adiponectin, and glucagon-like peptide-1 using path analysis. Dom. Anim. Endocrinol. 41:24-34.

[15] Blanchard G., Nguyen P., Gayet C., Leriche I., Siliart B. \& Paragon B.M. 2004. Rapid weight loss with a high-protein low-energy diet allows the recovery of ideal body composition and insulin sensitivity in obese dogs. J. Nutr. 134:2148S-2150S.

[16] Appleton D.J., Rand J.S. \& Sunvold G.D. 2005. Basal plasma insulin and homeostasis model assessment (HOMA) are indicators of insulin sensitivity in cats. J. Feline Med. Surg. 7:183-193.

[17] Sathiyapriya V., Nandeesha H., Bobby Z., Pavithran P., Selvaraj N. \& Dasse N.R. 2006. Insulin resistance and enhanced protein glycation in men with prehypertension. Clin. Chem. Lab. Med. 44:1457-1461.

[18] Vargas A.M., Barros R.P.A., Zampieri R.A., Okamoto M.M., Papa P.C. \& Machado U.F. 2004. Abnormal subcellular distribution of GLUT4 protein in obese and insulin-treated diabetic female dogs. Braz. J. Med. Biol. Res. 37:1095-1101.

[19] Respondek F., Swanson K.S. \& Belsito K.R. 2008. Short-chain fructooligosaccharides influence insulin sensitivity and gene expression of fat tissue in obese dogs. J. Nutr. 138:1712-1718.

[20] Marca M.C., Loste A. \& Ramos J.J. 2000. Effect of hyperglycaemia on serum fructosamine and blood glycated haemoglobin concentrations in canine samples. Vet. Res. Commun. 24:11-16.

[21] Watanabe D., Nakara H., Akagi K., Ishii T., Mizuguchi H., Nagashima Y. \& Okaniwa A. 2004. Oral glucose tolerance test and determination of serum fructosamine levels in Beagle dogs. J. Toxicol. Sci. 29:33-36.

[22] Martin L.J.M., Siliart B., Dumon H.J.W. \& Nguyen P.G. 2006. Hormonal disturbances associated with obesity in dogs. J. Anim. Physiol. Anim. Nutr. 90:355-360. 


\section{AUTHORS' BIOGRAPHY}

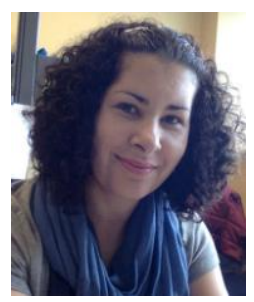

\section{Angela Patricia Medeiros Veiga, D.V.M., MSc., PhD}

Faculty member at the Veterinary Medicine Faculty from the Federal University of Santa Catarina (Curitibanos, Brazil). Her educational and research areas include Animal hematology, clinical biochemistry, and cytology.

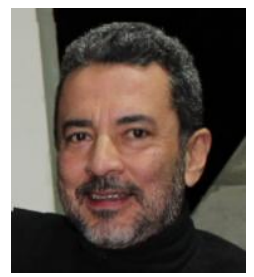

\section{Félix HilarioDíaz González, D.V.M., MSc., PhD}

Faculty member at the Veterinary Clinical Pathology Department from the Federal University of Rio Grande do Sul (Porto Alegre, Brazil). His educational and research areas include clinical biochemistry, metabolic profile, and metabolic and endocrine disorders.

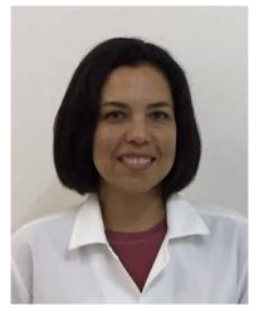

\section{Simone Tostes de Oliveira Stedile, D.V.M., MSc., PhD}

Professor of Department of Veterinary Medicine, Federal University of Parana, Brazil.

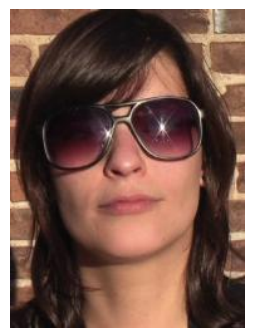

\section{Andrea Pires dos Santos, D.V.M., MSc., PhD}

Graduate TA - CPB Clinical Pathology, Purdue University College of Veterinary Medicine

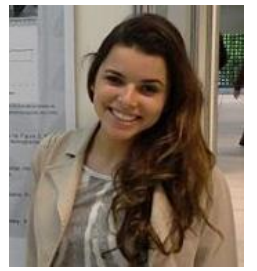

\section{WislleyYemanjáMalaquias dos Santos}

D.V.M Undergraduate Student, Universidade Federal de Santa Catarina (UFSC) Campus Curitibanos, Brazil 